\title{
KAJIAN TINGKAT KECELAKAAN FATAL, PENCEGAHAN DAN MITIGASI KECELAKAAN KAPAL-KAPAL PENANGKAP IKAN YANG BERBASIS OPERASI DI PPP TEGALSARI, PPN PEKALONGAN DAN PPS CILACAP
}

\author{
(ASSESSMENT ON FATALITY ACCIDENTS RATE, \\ PREVENTIONS AND MITIGATIONS OF THE FISHING VESSELS ACCIDENT \\ FROM FISHING BASE AT TEGALSARI COASTAL FISHING PORT, \\ PEKALONGAN ARCHIPELAGIC FISHING PORT AND CILACAP OCEANIC \\ FISHING PORT)
}

Djodjo Suwardjoํㅜ John Haluan², Indra Jaya ${ }^{2}$ dan Soen'an H. Poernomo ${ }^{3}$

\begin{abstract}
Safety performance of a fishing vessels fleet is indicated by the Fatality Accident Rate (FAR) of fishing vessels and the position of risk on F-N Curve, wether the risk position at unacceptable risk, intermediate risk or acceptable risk. The FAR of the fishing vessles, from fishing based at Tegalsari Coastal Fishing Port, Pekalongan Archipelagic Fishing Port and Cilacap Oceanic Fishing Port are 115 persons death/missing at sea per 100.000 fishermen per year and if it is compared with the FAR of the world fishing fleet, is still consider higher. Therefore, a necessary measures to reduce accident risk of fishing vessels accident with prevention and mitigation are needed. Some of the measures that we suggest to encompass the problem related to the fatal accident are: (1) training of navigation and safety competences for skippers and crew members;(2) increasing safety awareness for the fishing vessel owners, Fishing Port harbour master, fishing vessel inpectors, fisheries extension workers, instructors of fisheries education and training, community local leaders and fishermen families, (3)crews insurance, and (4) providing fishing vessel standard, ship manning standard and works in fishing standard, education, training and certification standar and standar of works in fishing.
\end{abstract}

Key words: Safety performance, Fatality Accident Rate (FAR, prevention and mitigation, training of navigation and safety competences, increasing of safety awareness.

\begin{abstract}
ABSTRAK
Kinerja keselamatan armada kapal-kapal penangkap ikan ditunjukkan dengan tingkat kecelakaan fatal kapal penangkap ikan dan posisi risiko kecelakaan armada kapal penangkap apakah berada pada posisi yang unacceptable risk, intermediate risk atau acceptable risk. Tingkat Kecelakaan Fatal armada kapal di PPP Tegalsari, PPN Pekalongan dan PPS Cilacap menunjukkan angka 115 orang meninggal per 100.000 awak kapal pertahun dan masih lebih tinggi bila dibanding tingkat kecelakaan fatal kapal penangkap ikan tingkat dunia, yakni 80 orang meninggal/100.000 awak kapal. Posisi risiko kecelakaan berada pada posisi yang unacceptable risk artinya perlu upaya penurunan risiko kecelakaan dalam kurun waktu satu tahun. Diperlukan upaya pencegahan dan mitigasi untuk menurunkan risiko kecelakaan melalui berbagai hal, yaklni: (1) pelatihan kompetensi keselamatan dan pelayaran bagi para nakhoda dan ABK, (2) peningkatan safety awareness bagi pemilik kapal, Syahbandar pelabuhan perikanan, pengawas kapal perikanan, penyuluh perikanan tangkap, pengajar pada lembaga pendidikan dan pelatihan perikanan, pemuka masyarakat nelayan dan keluarga nelayan, penegakan hukum atas keselamatan kapal perikanan, (3) asuransi awak kapal, (4) membangun standar pendidikan dan pelatihan dan sertifikasi pelaut perikanan, standar kapal penangkap ikan, standar pengawakan dan membangun sistem ketenagakerjaan pada kapal penangkap ikan.
\end{abstract}

Kata kunci: Kinerja keselamatan, Tingkat Kecelakaan Fatal, pencegahan dan mitigasi, pelatihan kompetensi navigasi dan keselamatan, peningkatan safety awareness.

\section{PENDAHULUAN}

Penangkapan ikan di laut merupakan pekerjaan yang paling membahayakan di dunia. FAO (2000), memperkirakan terdapat 36 juta orang yang terlibat dalam kegiatan penangkapan ikan dan budidaya perikanan, 15 juta diantaranya terlibat dalam

\footnotetext{
${ }^{1}$ Staf Ditjen P2HP, Kementrian Kelautan dan Perikanan

${ }^{2}$ Staf pengajar Fakultas Perikanan dan Ilmu Kelautan IPB

${ }^{3}$ Kepala Pusat Statistik dan Informasi, Sekjen KKP
} 

kegiatan penangkapan ikan dan budidaya perikanan, 15 juta diantaranya terlibat dalam penangkapan ikan di laut, 90\% nelayan bekerja pada kapal-kapal berukuran panjang kurang dari $24 \mathrm{~m}$. Profesi pelaut kapal penangkap ikan memiliki karakteristik pekerjaan bersifat "3d" yaitu: membahayakan (dangerous), kotor (dirty) dan sulit (difficult). ILO memperkirakan terdapat 24.000 kecelakaan fatal pertahun di seluruh dunia.

Pelaut kapal penangkap ikan berlayar menempuh alur pelayaran yang tidak menentu, tidak seperti alur pelayaran kapal-kapal niaga, namun disesuaikan dengan daerah penangkapan ikan yang menjadi sasaran penengkapan yang kerap berpindah-pindah. Adapun lama pelayaran kapal-kapal penangkap ikan sangat bervariasi tergantung ukuran kapal, musim penangkapan atau faktor lain seperti cuaca yang tidak memungkinkan untuk melaut. Kapal-kapal berukuran kecil biasanya berlayar hanya satu hari (one day fishing) sedangkan kapal besar bisa mencapai hingga tiga bulan mengingat perbekalan dan bahan bakar biasanya disuplai kapal pengangkut ikan.

Armada kapal penangkap ikan dunia didominasi kapal-kapal berukuran panjang kurang dari $24 \mathrm{~m}$ atau $98 \%$ berukuran kecil (Petursdattir et al., 2001). Di Indonesia, pada tahun 2008 armada kapal panangkap ikan berjumlah 555.190 unit kapal dan 94\% diantaranya berukuran di bawah 60 GT dengan jumlah nelayan sebanyak 3,4 juta orang (Direktorat Jenderal Perikanan, 2009). Diantara kapal-kapal berukuran kecil tersebut diantaranya kapal cantrang (dogol), kapal purse-seine, kapal longline dan kapal gillnet.

Kapal-kapal berukuran antara 10-30 GT yang berbasis di PPP Tegalsari didominasi kapal-kapal cantrang dan gillnet banyak dioprasikan disepanjang pantai utara Pulau Jawa, Perairan Madura, Perairan Pulau Masalembo bahkan ada yang berlayar sampai di perairan Kalimantan. Kapal-kapal yang berbasis di Pekalongan umunya memiliki ukuran kapal 20-120 GT didominasi kapal purse-seine beroperasi lebih jauh, yakni ke perairan Natuna, Bangka Belitung, Pulau Masalembu, Selat Makasar, Perairan Matasiri. Adapun kapal-kapal penangkap ikan di perairan Cilacap berukuran 10-60 GT berperasi disekitar perairan Cilacap, Perairan selatan Gombong dan perairan selatan Pangandaran.
Memperhatikan ukuran kapal yang relatif kecil dan kondisi cuaca yang tidak menentu dimungkinkan akibat pemanasan global, serta kapal diawaki dengan jumlah orang yang melebihi kapasitas karena menggunakan teknologi sederhana maka kemungkinan terjadi kecelakaan pada kapal penangkap ikan sangat besar. Permasalahan keselamatan pada setiap kapal dan setiap pengoperasian masingmasing jenis alat tangkap memiliki tingkat keselamatan berbeda.

Menurut Jennifer et al. ( 2002) bahwa keselamatan kapal penangkap ikan merupakan interaksi faktor-faktor yang kompleks yakni human factor (nakhoda dan anak buah kapal), machines (kapal dan peralatan keselamatan) dan environmental (cuaca dan skim pengelolaan sumberdaya perikanan). Permasalahan keselamatan atau kecelakaan akan timbul apabila salah satu elemen dari human factor, machines atau enviromental factor tersebut tidak berfungsi. Banyak faktor yang dapat meningkatkan risiko kecelakaan adalah: kondisi jam kerja yang relatif lama sehingga menyebabkan kelelahan; kondisi kapal yang tua dan kurang terawat; ruang kerja yang sempit; bahaya yang melekat pada pekerjaan (seperti kondisi cuaca); kurang terampil dan kurang pelatihan; kurangnya monitoring dan performance keselamatan kapal; produk yang ditangani membahayakan seperti ikan berbisa; kurangnya peralatan dan penggunaan peralatan keselamatan.

Pendataan dan investigasi kecelakaan kapal penangkap ikan masih kurang mendapat perhatian. Melalui pendataan dan investigasi dapat diketahui faktorfaktor penyebab terjadi kecelakaan, bagaimana kecelakaan terjadi, tindakantindakan yang dilakukan nakhoda dan anak buah kapal untuk menghindari dan mengatasi kecelakaan, probabilitas kejadian, konsekuensi atau tingkat kerusakan terhadap kapal dan lingkungan, risiko terhadap awak kapal, kerugian jiwa, harta dan lingkungan, tingkat kecelakaan fatal (Fatality Accidents Rate, FAR) serta kinerja keselamatan suatu armada penangkapan ikan.

Risk Index menggambarkan tingkat risiko kegiatan penangkapan ikan oleh kapal-kapal dalam suatu unit armada, memberikan gambaran apakah tingkat risiko berada pada tingkat: unacceptable risk, intermediate risk, atau acceptable risk. Apabila tingkat risiko dan penyebab 
kecelakaan diketahui maka kegiatan penangkapan bisa saja terpaksa dihentikan karena berada pada posisi sangat membahayakan, atau kegiatan penangkapan dapat dilanjutkan dengan melalui upaya pencegahan dan mitigasi guna menurunkan risiko kecelakaan. Selain risk index juga dapat diketahui dari suatu armada perikanan tangkap. FAR merupakan perbandingan jumlah awak kapal yang meinggal atau hilang di laut setiap 100.000 orang awak kapal.

Dalam makalah ini diuraikan hasil:

(1) Identifikasi profil Nakhoda kapal sebagai pemegang komando di atas kapal penangkap ikan dan kondisi peralatan keselamatan kapal;

(2) Identifikasi dan analisis risiko kecelakaan fatal yang terjadi pada armada kapal penangkap ikan yang berbasis operasi di PPP Tegalsari, PPN Pekalongan dan PPS Cilacap; dan

(3) Analisis alternatif solusi pencegahan dan mitigasi risiko kecelakaan kapal penangkap ikan.

\section{METODE PENELITIAN}

Pengumpulan data primer dilakukan melalui institusi terkait yakni Syahbandar Pelabuhan Perikanan, Himpunan Nelayan Seluruh Indonesia (HNSI), Satuan Polair, Dinas Kelautan dan Perikanan dan institusi terkait lainnya, sedangkan data sekunder dikumpulkan dari berbagai sumber.

Identifikasi kecelakaan yang dikumpulkan dari data kecelakaan yang tersedia dalam kurun waktu tiga tahun. Kecelakaan kapal didata oleh Satuan Polisi Air di pelabuhan dan HNSI cabang Kabupaten/Kota dengan format berbeda dan kelengkapan data belum memadai. Data kecelakaan meliputi nama kapal, lokasi kecelakaan, jumlah korban meninggal/hilang dan indentifikasi korban, jenis kecelakaan dan uang duka yang diperoleh keluaraga korban. Kecelakaan kapal penangkap ikan yang didata hanya kecelakaan fatal yakni kecelakaan kapal yang mengakibatkan meninggal/hilangnya awak kapal dan atau hilangnya kapal, tidak termasuk kecelakaan berat dan ringan.

Analisis risiko kecelakaan dilakukan dengan menghitung FAR dan RI dari data kecelakaan yang ada dalam tiga tahun terakhir. Penyebab kecelakaan kematian awak kapal, kemampuan awak kapal dalam menghadapi kecelakaan, ketrampilan awak kapal dalam menangani kecelakaan, kondisi dan informasi cuaca, waktu kejadian penting untuk diketahui guna merancang tindakan-tindakan pencegahan dan mitigasi kecelakaan kapal.

Pengukuran FAR dengan membandingkan jumlah korban meninggal/hilang pertahun dengan jumlah awak kapal aktif per 100.000 awak kapal. Pengukuran Risk Index dari suatu armada penangkapan dengan menggambarkan peluang kecelakaan dan tingkat konsekuensi pada Kurva F-N. Risiko suatu kecelakaan kapal merupakan perkalian antara Frekuensi (Probability) dan Konsekuensi atau tingkat pengaruh kecelakaan terhadap korban manusia dan/atau kapal.

Risiko= Frekuensi $\mathrm{x}$ Konsekuensi

atau

$\log ($ Risiko $)=\log ($ Frekuensi $)+\log$

(Konsekuensi)

Pada Tabel 1 menggambarkan Konsekuensi (Severity Index,SI) yang menunjukkan tingkat efek kecelakaan kepada manusia dan kapal dan Tabel 2 menggambarkan frekuensi indeks.

Tabel 1 Logaritmic Severity Index (Paulsson 1999, dalam Forsman, 2004)

\begin{tabular}{|c|c|c|c|}
\hline $\begin{array}{c}\text { Tingkat Kekerasan } \\
\text { Kecelakaan } \\
\text { (Severity) }\end{array}$ & $\begin{array}{c}\text { Pengaruh kepada } \\
\text { keselamatan awak kapal }\end{array}$ & $\begin{array}{c}\text { Pengaruh terhadap } \\
\text { kapal }\end{array}$ & $\begin{array}{l}\text { S (equivalent } \\
\text { fatalities) }\end{array}$ \\
\hline $\begin{array}{l}\text { Sangat ringan } \\
\text { (Minor) }\end{array}$ & Satu luka ringan & $\begin{array}{l}\text { Perlengkapan kapal } \\
\text { rusak ringan }\end{array}$ & 0.01 \\
\hline Ringan & $\begin{array}{l}\text { Banyak luka ringan atau } \\
\text { beberapa luka berat }\end{array}$ & Kapal rusak ringan & 0.1 \\
\hline Sedang (Major) & $\begin{array}{l}\text { Satu awak kapal meninggal } \\
\text { atau banyak luka berat }\end{array}$ & Kapal rusak berat & 1 \\
\hline Berat & $\begin{array}{l}\text { Awak kapal meninggal } \\
\text { meninggal } 2-10 \text { orang }\end{array}$ & $\begin{array}{l}\text { Kapal rusak sangat } \\
\text { berat }\end{array}$ & 10 \\
\hline $\begin{array}{l}\text { Sangat berat } \\
\text { (Catastrophic) }\end{array}$ & $\begin{array}{l}\text { Awak kapal meninggal >10 } \\
\text { orang }\end{array}$ & $\begin{array}{l}\text { Kapal tenggelam } \\
\text { (Total loss) }\end{array}$ & 100 \\
\hline
\end{tabular}


Tabel 2 Frequency Index (FI) (Paulsson dalam Forsman, 2004)

\begin{tabular}{lll}
\hline \multicolumn{1}{c}{ Frequency } & \multicolumn{1}{c}{ Definition } & \multicolumn{1}{c}{ F (per ship year) } \\
\hline Sangat tinggi & Kecelakaan terjadi > 10\% dari armada kapal & \\
& $\begin{array}{l}\text { pertahun } \\
\text { Kecelakaan terjadi 1 - <10\% pertahun }\end{array}$ & 1 \\
Sedang & Kecelakaan terjadi 1 kapal pertahun & 0.1 \\
Jarang & Kecelakaan terjadi 1 kapal per 10 tahun & 0.01 \\
Sangat Jarang & Kecelakaan terjadi 1 kapal per 100 tahun & 0.001 \\
\hline
\end{tabular}

Tabel 3 berikut menggambarkan risk matrix berdasarkan Tabel 1 dan Tabel 2, yang menghasilkan Risk Index (RI). Risk Index menunjukkan posisi tingkat risiko penangkapan secara agregat sehingga para pemangku kepentingan dapat melakukan upaya-upaya preventif dan mitigasi. Angka RI bernilai 2-4 menunjukkan bahwa risiko kecelakaan dapat diterima, kegiatan dapat dilanjutkan tetapi harus yakin bahwa keadaan tidak akan lebih buruk, angkat RI bernilai 5-6 berada pada tingkat intermediate risk, perlu mengambil langkah/tindakan yang diperlukan dalam kurun satu tahun, sedangkan angka RI bernilai 7-10 menunjukkan tingkat kecelakaan dengan risiko paling membahayakan (unacceptable risk) memerlukan tindakan pencegahan dan mitigasi sesegera mungkin.

Alternatif pencegahan dan mitigasi terhadap kecelakaan kapal ditinjau dari aspek sumberdaya manusia awak kapal, perlengkapan keselamatan dan kelembagaan.

Tabel 3 Risk Index (RI) (Paulsson dalam Forsman, 2004)

\begin{tabular}{|c|l|c|c|c|c|c|}
\hline \multicolumn{9}{|c|}{ Risk Index (RI) } \\
\hline FI & Frequency & $\begin{array}{c}\text { Sangat ringan } \\
\text { (Minor) }\end{array}$ & Ringan & $\begin{array}{l}\text { Sedang } \\
\text { (Major) }\end{array}$ & Berat & $\begin{array}{l}\text { Sangat Berat } \\
\text { (Catastrophic) }\end{array}$ \\
\hline 5 & Sangat tinggi (Frequent) & 6 & 7 & 8 & 9 & 10 \\
\hline 4 & $\begin{array}{l}\text { Tinggi (Reasonably } \\
\text { Probable) }\end{array}$ & 5 & 6 & 7 & 8 & 9 \\
\hline 3 & Sedang (probable) & 4 & 5 & 6 & 7 & 8 \\
\hline 2 & Rendah (remote) & 3 & 4 & 5 & 6 & 7 \\
\hline 1 & $\begin{array}{l}\text { Sangat rendah (Extremely } \\
\text { remote) }\end{array}$ & 2 & 3 & 4 & 5 & 6 \\
\hline
\end{tabular}

\section{HASIL PENELITIAN}

\subsection{Profil Nakhoda Kapal Penangkap} Ikan

Nakhoda kapal adalah seseorang dari awak kapal yang mempunyai kewenangan komando di atas sebuah kapal dan memiliki tanggung jawab atas keselamatan awak kapal dan kapal yang dioperasikannya (UU 17 Tahun 2008 tentang Pelayaran). Nakhoda dan awak kapal penangkap ikan harus memiliki kepedulian keselamatan (safety awareness), keahlian bernavigasi, ketrampilan keselamatan, ketrampilan komunikasi radio, ketrampilan penangkapan dan penanganan hasil tangkapan (STCW-F 1995, KM 9 Tahun 2005). Pada Bab III STCW-F 1995 Pasal 1 menyatakan bahwa sebelum melaksanakan tugas-tugas di atas kapal penangkap ikan, seluruh awak kapal penangkap ikan diwajibkan menerima pelatihan Basic Safety Training for Fishing Vessel Personnel (BST-F), yang meliputi materi: 1) Teknik penyelamatan diri termasuk penggunaan jaket penolong (life jacket) dan baju cebur (immersion suits); 2) Pencegahan dan pemadaman kebakaran; 3) Prosedur darurat; 4) Pertolongan Pertama Pada Kecelakaan (P3K); 5) Pencegahan polusi laut; dan 6) Pencegahan kecelakaan di atas kapal.

Menurut IMO (1995), Nakhoda dan perwira jaga kapal penangkap ikan harus memiliki pengetahuan dan ketrampilan minimal sesuai dengan ukuran kapal dan daerah pelayaran. Semakin besar ukuran kapal dan beroperasi di perairan laut lepas atau unlimited waters maka kesulitan pelayaran semakin tinggi sehingga minimal pengetahuan dan keahlian yang harus dimiliki seorang nakhoda dan perwira jaga semakin kompleks. Kemampuan keahlian harus dibuktikan 
dengan sertifikat kompetensi dan sertifikat profisiensi berstandar internasional.

Menurut IMO (2007), Nakhoda kapal kecil harus memiliki kompetensi kerja yang memadai dalam mengoperasikan kapal secara aman dan selamat, mengelola kapal dengan baik secara terus menerus, meliputi:

(1.) Pengoperasian dan perawatan mesin;

(2.) Menangani keadaan darurat dan menggunakan radio komunikasi untuk meminta pertolongan;

(3.) Pertolongan Pertama pada Kecelakaan (P3K);

(4.) Mengolah gerak kapal di laut, di pelabuhan dan selama operasi penangkapan;

(5.) Navigasi;

(6.) Kondisi cuaca dan ramalan cuaca;

(7.) Stabilitas kapal;

(8.) Penggunaan sistem signal;
(9.) Pencegahan kecelakaan;

(10.) Peraturan Pencegahan Tubrukan di Laut;

(11.) Memahami dan meminimalkan risiko operasi penangkapan ikan.

Untuk menguasai keahlian atau ketrampilan tersebut maka seorang nakhoda kapal minimum berpendidikan menengah perikanan seperti Sekolah Usaha Perikanan Menengah atau pendidikan SLTA umum ditambah pelatihan kepelautan meliputi pelayaran dan pengoperasian kapal, keselamatan dan penangkapan ikan.

Hasil penelitian menunjukkan bahwa latar pendidikan para Nakhoda kapal penangkap ikan yang berbasis operasi di PPP Tegalsari, PPN Pekalongan dan PPS Cilacap dengan ukuran bobot kapal 10 - <120 GT, seperti pada Tabel 4.

Tabel 4 Latar Belakang Pendidikan Formal Nakhoda Kapal Penangkap Ikan di PPP Tegalsari, PPN Pekalongan dan PPS Cilacap

\begin{tabular}{llc}
\hline No. & Tingkat Pendidikan & Prosentase \\
\hline 1. & Tidak tamat SD & $14,0 \%$ \\
2. & SD & $70,3 \%$ \\
3. & SLTP & $10,9 \%$ \\
4. & SLTA & $4,8 \%$ \\
5. & Perguruan Tinggi & $0 \%$ \\
\hline
\end{tabular}

Untuk memenuhi persyaratan para Nahkoda telah memiliki sertifikat kompetensi kepelautan sesuai dengan ukuran kapal dan daerah operasi penangkapannya, seperti SKK 60 mil Plus, SKK 60 mil atau SKK 30 mil, yang diterbitkan oleh Syahbandar pelabuhan niaga dan masih sangat sedikit yang sudah memiliki sertifikat ANKAPIN-III. Sertifikat ANKAPIN-III diterbitkan sesuai dengan Peraturan Pemerintah Nomor 7 Tahun 2000 diterbitkan oleh Direktorat Jenderal Perhubungan Laut, yang didahului dengan pelatihan yang diselenggarakan oleh Balai Pendidikan dan Pelatihan Perikanan (BPPP), Departemen Kelautan dan Perikanan atau balai latihan perikanan lainnya. Setelah Desember 2009 sertifikat kompetensi kepelautan yang diharuskan dimiliki Nakhoda ANKAPIN-III untuk bagian dek dan ATKAPIN-III untuk bagian mesin.

Walaupun sudah memiliki sertifikat kompetensi di atas, dari hasil penelitian para Nakhoda belum memenuhi kualifikasi kompetensi minimal yang disyaratkan dalam STCW-F 1995 (KM 09/2005).
Akibat dari tidak dimilikinya kompetensi keselamatan oleh para Nakhoda maka kesadaran terhadap pentingnya keselamatan pelayaran dan penangkapan ikan (safety awareness) bagi awak kapal masih rendah.

Setelah diberlakukannya UndangUndang Nomor 17 Tahun 2008 tentang Pelayaran, para perwira pada kapal yang berukuran panjang kurang dari $12 \mathrm{~m}$ harus memiliki sertifikat kepelautan ANKAPIN-III untuk bagian dek dan ATKAPIN-III untuk bagian mesin, sementara itu seluruh awak kapal (Nakhoda dan ABK) kapal penangkap ikan diwajibkan memiliki kompetensi keselamatan. yang diperoleh melalui Pelatihan Keselamatan Tingkat Dasar (Basic Safety Training, BST).

Salah satu persyaratan peserta untuk mengikuti pelatihan BST harus lulusan SLTP maka hal ini menimbulkan masalah di masyarakat nelayan dimana para Nakhoda dan ABK kapal penangkap ikan $84,3 \%$ tidak berpendidikan SLTP atau hanya $15,7 \%$ dari Nakhoda yang layak mengikuti pelatihan BST. 
Kemampuan menangkap ikan yang dimiliki para nelayan sudah memadai namun kemampuan bernavigasi dan keselamatan masih memerlukan peningkatan. Hasil penelitian menunjukkan bahwa penguasaan kompetensi navigasi dan keselamatan, sebagai berikut: $37,92 \%$ sangat kurang kompeten, 36,16 kurang kompeten, $14,50 \%$ cukup kompeten, $9,62 \%$ kompeten dan $1,8 \%$ sangat kompeten.

Setiap Nakhoda rata-rata menanggung beban hidup anggota keluarga sebanyak 7 orang, dan belum ada asuarnsi kecelakaan atau asuransi jiwa bagi Nakhoda dan ABK.

\subsection{Kondisi Peralatan Keselamatan Kapal Penangkap Ikan yang Berbasis Operasi di PPP Tegalsari, PPN Pekalongan dan PPS Cilacap}

Sesuai dengan Keputusan Menteri Perhubungan Nomor KM 46 tahun 1996 yang masih dijadikan dasar hukum untuk penerbitan Sertifikat Kelaiklautan dan Pengawakan Kapal Penangkap Ikan, maka perlengkapan keselamatan yang harus tersedia di kapal penangkap ikan menyangkut jumlah, kapasitas, atau penempatan pada lambung kiri atau lambung kanan kapal, adalah: skoci penolong (life boat), skoci kerja (work boat), rakit penolong kembung (inflatable liferaft), rakit penolong tegar (rigid liferaft), baju/jaket penolong (life jacket), baju cebur (immersion suits), sarana pelindung panas (thermal protective aids), pelampung penolong dengan lampu dan asap (life buoy with light and smoke), pelampung penolong dengan lampu dan tali (life buoy with light and line), pelampung penolong biasa (ordinary life buoy), perangkat telekomunikasi radio teleponi (Radio telephone apparatus), perangkat telekomunikasi radio VHF (VHF radio telephone apparatus), perangkat EPIRB (EPIRB apparatus), perangkat komunikasi VHF radio telephone dua arah (two way VHF radio telephone apparatus), transfonder radar $9 \mathrm{GHz}$ (radar transfonder $9 \mathrm{GHz}$ ), pesawat penerima NAVTEX (NAVTEX receiver), peralatan pencegahan minyak (oil pollution prevention equipment). Pada daftar perlengkapan tersebut tidak tercantum perlengkapan kesehatan dan obat-obatan, helem kerja, baju kerja, sarung tangan, dan sepatu kerja.

Hasil penelitian menunjukkan, sebagai berikut:

(1.) Kapal-kapal Cantrang di PPP Tegalsari
Kapal cantrang yang berbasis operasi di PPP Tegalsari dari jumlah sampling sebanyak 21 kapal, dengan bobot kapal antara 12-30 GT, ukuran panjang kapal keseluruhan (LOA) 8-20 m, sebanyak tiga unit kapal atau $14,29 \%$ telah memenuhi persyaratan peralatan keselamatan, 18 unit kapal atau 85,71\% tidak memenuhi persyaratan peralatan keselamatan. Kekurangan peralatan pada kapal-kapal minipurse-seine, diantaranya jumlah jaket penolong (life jacket) tidak sesuai dengan jumlah awak kapal, jumlah pelampung penolong (life buoy) kurang, tidak dilengkapi alat pemadam kebakaran, tidak ada rakit penolong, tidak dilengkapi helm, sepatu kerja dan pakaian kerja, kotak P3K kurang lengkap.

(2.) Kapal-kapal purse-seine di PPN

Pekalongan

Kapal-kapal purse-seine yang berbasis operasi di PPN Pekalongan memiliki bobot antara 29-129 GT dengan LOA 19,95-26,5 m. Dari sampling kapal sebanyak 22 kapal menunjukkan sebanyak empat unit kapal atau sebanyak $18,18 \%$ telah dilengkapi peralatan keselamatan. Sementara sebanyak 18 unit kapal atau $81,82 \%$ tidak memenuhi persyaratan keselamatan. Kekurangan peralatan pada kapal-kapal mini purseseine, diantaranya jumlah jaket penolong (life jacket) tidak sesuai dengan jumlah awak kapal, jumlah pelampung penolong (life buoy) kurang, tidak dilengkapi alat pemadam kebakaran, tidak ada rakit penolong, tidak dilengkapi helem, sepatu kerja dan pakaian kerja, kotak P3K kurang lengkap.

(3.) Keragaan Peralatan Keselamatan

Kapal-kapal Minilongline di PPS

Cilacap

Kapal-kapal Minilongline di PPS Cilacap dengan sampling 21 unit kapal, kisaran bobot kapal antara 22-56 GT, LOA 15,8-22 m, menunjukkan bahwa kapal telah memenuhi perlengkapan kapal dan peralatan keselamatan sebanyak 12 kapal atau sebesar $57,14 \%$ dan 9 kapal atau $42,86 \%$ tidak memenuhi persyaratan peralatan keselamatan kapal.

Kekurangan peralatan keselamatan pada kapal-kapal minilongline yang berbasis operasi di PPS Cilacap, diantaranya kekurangan jumlah jaket penolong (life jacket) belum sesuai dengan jumlah awak kapal, alat pemadam kebakaran, rakit penolong, dan pelampung penolong (life buoy). Selain itu masih ada 
beberapa kapal yang tidak dilengkapi alat komunikasi Radio SSB dan alat navigasi seperti penentu posisi kapal Global Positioning Systems (GPS).
Prosentase kapal-kapal penangkap ikan yang layak /tidak layak, yang berbasis operasi di PPP Tegalsari, PPN Pekalongan dan PPS Cilacap sebagaimana pada Gambar 1 dan Tabel 5.

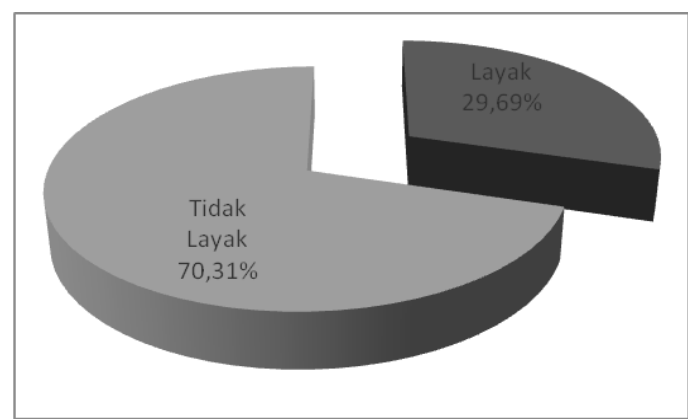

Gambar 1 Grafik Kondisi Kelayakan Kapal Penangkap Ikan 10-129 GT yang berbasis Operasi di PPP Tegalsari, PPN Pekalongan dan PPS Cilacap.

Tabel 5 Kondisi kelaiklautan kapal Cantrang, Minipurse-seine dan Minilongline menurut kondisi peralatan keselamatan

\begin{tabular}{llcccc}
\hline No & Jenis Kapal & \multicolumn{2}{c}{ Layak } & \multicolumn{2}{c}{ Tidak Layak } \\
& & Jumlah & $\%$ & Layak & Tidak Layak \\
\hline 1. & Cantrang & 3 & 14,29 & 18 & $85,71 \%$ \\
2. & Minipurse-seine & 4 & 18,18 & 18 & $81,82 \%$ \\
3. & Minilongline & 12 & 57,14 & 9 & $42,86 \%$ \\
\hline & Jumlah & 19 & 29,69 & 45 & $70,31 \%$ \\
\hline
\end{tabular}

Kapal dikategorikan laiklaut kapal penangkap ikan apabila kapal penangkap ikan telah memenuhi persyaratan kapal yang meliputi:

(1.) Konstruksi dan tata susunan kapal;

(2.) Stabilitas dan garis muat kapal;

(3.) Perlengkapan kapal termasuk peralatan keselamatan;

(4.) Permesinan dan listrik kapal;

(5.) Sistem dan perlengkapan pencegahan dan pemadam kebakaran;

(6.) Sistem dan perlengkapan pencegahan pencemaran dari kapal;

(7.) Alat tangkap, cara menangkap, penanganan hasil tangkap sesuai peraturan yang berlaku;

(8.) Jumlah dan susunan awak kapal.

Kapal dinyatakan laiklaut dibuktikan dengan dokumen berupa sertifikat kelaiklautan kapal, yakni: Surat Laut untuk kapal yang memiliki volume kotor $500 \mathrm{~m} 3$ atau 175 GT; Pas Tahunan bagi kapal yang memiliki volume kotor kapal 20 m3 atau 7 GT; Pas Putih : isi kotor kapal $\geq 10-<20$ m3, dan Pas Biru bagi kapal yang memiliki volume kotor $<10 \mathrm{~m} 3$ atau 3 GT.

\subsection{Laju Kecelakaan Fatal (LKF) atau Fatality Accident Rate (FAR) kapal- kapal penangkap ikan yang}

\section{berbasis operasi di PPP Tegalsari, Kota Tegal. PPN Pekalongan dan PPS Cilacap.}

Statistik kecelakaan kapal dan investigasi kecelakaan kapal sangat diperlukan dalam pengembangan sistem pencegahan dan mitigasi guna menurunkan tingkat kecelakaan. Safety performance dari armada kapal penangkap ikan secara agregat perlu diketahui dengan cara melakukan analisis terhadap berbagai aspek yang mendukung tingkat keselamatan dan kejadian-kejadian kecelakaan kapal penangkap ikan.

Masing-masing kapal penangkap ikan sebagai individu memiliki tingkat keselamatan berbeda tergantung kepada penguasaan kompetensi keselamatan oleh Nakhoda dan ABK-nya, kondisi kelaikan kapal dan perlengkapannya, kondisi alat tangkap, serta faktor luar seperti cuaca dan kondisi perairan.

Indonesia belum memiliki data Laju Kecelakaan Fatal atau FR baik tingkat kabupaten, provinsi atau nasional, hal ini disebabkan masih belum terstrukturnya pendataan kecelakaan kapal penangkap ikan dan instansi apa yang memiliki kewenangan untuk melaksanakan pendataan pada tingkaat kabupaten/kota, provinsi dan nasional. 
Hasil penelusuran di lapangan, pendataan kecelakaan kapal di tiga lokasi penelitian yaitu di PPP Tegalsari, PPN Pekalongan dan PPS Cilacap, pendataan kecelakaan kapal penangkap ikan dilakukan oleh Himpunan Nelayan Seluruh Indonesia (HNSI) cabang kabupaten/kota dikaitkan dengan pengeluaran dana sosial uang duka dari koperasi nelayan dan Satuan POLAIR.

Pencatatan data kecelakaan kapal tersebut hanya data kecelakaan dengan korban meninggal atau hilang dan kecelakaan yang menyebabkan kapal tenggelam walaupun awak kapal dapat diselamatkan, namun belum termasuk kecelakaan dengan korban luka-luka berat dan luka ringan.

Jumlah kecelakaan fatal kapal penangkap ikan yang terjadi dilokasi penelitian dari tahun 2006 sampai 2008, sebanyak 61 kali kecelakaan fatal dengan korban awak kapal meninggal/hilang di laut sebanyak 68 orang atau rata-rata pertahun korban meninggal/hilang sebanyak 32 orang dari jumlah awak kapal aktif sebanyak 19.640 orang. Kapal dan alat tangkap yang tenggelam/hilang di laut sebanyak 22 unit kapal atau ratarata kapal hilang sebanyak 7 unit/tahun.

Laju Kecelakaan Fatal (LKF) atau Fatality Rate (FR) dihitung jumlah korban meninggal/hilang per 100.000 nelayan. LKF di masing-masing lokasi penelitian sebagai berikut: di PPP Tegalsari 123 orang meninggal/100.000 orang awak kapal, PPN Pekalongan 46 orang meninggal/100.000 orang awak kapal, dan PPS Cilacap 235 orang meninggal/100.000 awak kapal. Rata-rata LKF di tiga lokasi penelitian tersebut adalah 115 orang meninggal/100.000 nelayan.

Bila dibandingkan dengan rata-rata tingkat kecelakaan fatal kapal penangkap ikan dunia pekerjaan nelayan atau awak kapal penangkap ikan mencapai 80/100.000 awak kapal pertahun (ILO, FAO (2000) dalam Jennifer et al., (2002) memperkirakan $7 \%$ dari seluruh kecelakaan kerja fatal di dunia terjadi pada industri perikanan tangkap. Pada industri perikanan tangkap di seluruh dunia berdasarkan pengalaman, terdapat 24.000 kecelakaan fatal.
Di Australia, antara tahun 1982 sampai 1984, tingkat kecelakaan fatal sebesar 18 kali lebih tinggi dari rata-rata tingkat kecelakaan nasional Australia $(143 / 100.000$ orang dibanding 8.1/100,000); di Denmark, dari tahun 1989 sampai 1996, tingkat kecelakaan pada kapal penangkap ikan 25-30 kali lebih tinggi disbanding tingkat kecelakaan pekerja di daratan. Di negara-negara Nordic menunjukkan bahwa kecelakaan fatal antara 90 sampai 150 orang per 100.000 pekerja. Upaya-upaya pencegahan kecelakaan, pelatihan survival dan pelayanan SAR di negara tersebut termasuk salah satu diantara negaranegara yang terbaik di dunia. Selanjutnya disebutkan dari negara berkembang seperti Sri Lanka untuk perikanan tangkap laut dalam (offshore fishing) 10 kali lebih tinggi dibanding kecelakaan fatal di Norwegia. Studi kecelakaan fatal penangkapan, dengan perahu kano di Guinea tahun 1991-1994 menunjukkan 500 orang per 100.000 pekerja; di sepanjang pantai Afrika Barat, penangkapan ikan tradisional dengan kano, kecelakaan fatal antara 300-1000 orang per 100.000 pekerja. Di Afrika Selatan angka kecelakaan fatal 585 orang per 100.000 nelayan.

Menurut Petursdottir (2001), di Amerika Serikat tahun 1996 tingkat kematian dalam perikanan diperkirakan delapan kali lebih tinggi dibanding orang yang mengoperasikan kendaraan dan 16 kali lebih tinggi dibanding petugas pemadam kebakaran dan polisi, serta 40 kali dari rata-rata kecelakaan fatal nasional. Laju kecelakaan fatal lainnya (dimana $\mathrm{x}$ merupakan rata-rata laju kecelakaan fatal nasional negara tersebut); Republik Korea (15 x); Estonia (11 x); Italy $(21 \mathrm{x})$; Lithuania (11 x); Polandia (9 x); Spanyol $(6 \quad \mathrm{x})$ dan Canada (3,5 x). Di Australia, kecelakaan yang terjadi antara 1982 sampai 1984, laju kecelakaan fatal (fatality rate) nelayan adalah 18 kali lebih tinggi rata-rata kecelakaan fatal secara nasional $(143 / 100.000$ orang-tahun dibanding $8,1 / 100.000$ ).

Perbandingan tingkat kecelakaan fatal kapal penangkap ikan yang berbasis operasi di Pantai Utara Jawa dan Selatan Jawa ditunjukkan pada Tabel 6. 
Tabel 6 Perbandingan Kecelakaan Fatal Perairan Utara Jawa (PPP Tegalsari dan PPN Pekalongan) dan perairan Selatan Jawa (PPS Cilacap) Tahun 2006-2008

\begin{tabular}{|c|c|c|}
\hline Uraian & Perairan Utara Jawa & Perairan Selatan Jawa \\
\hline $\begin{array}{l}\text { LKF (jumlah meninggal/hilang } \\
\text { per } 100.000 \text { awak kapal) }\end{array}$ & 78 & 235 \\
\hline Jumlah kecelakaan fatal & 36 & 24 \\
\hline Jumlah korban meninggal/hilang & 35 & 33 \\
\hline $\begin{array}{l}\text { Unit Kapal dan alat tangkap } \\
\text { hilang/tahun }\end{array}$ & 3 & 4 \\
\hline $\begin{array}{l}\text { Prosentase Kecelakaan kapal per } \\
100 \text { kapal }\end{array}$ & 1,8 & 1,2 \\
\hline $\begin{array}{l}\text { Waktu kecelakaan relatif tertinggi } \\
\text { (bulan) }\end{array}$ & $\begin{array}{l}\text { November, Desember, } \\
\text { Januari, Februari }\end{array}$ & Juli \\
\hline
\end{tabular}

Kecelakaan fatal kapal-kapal yang beroperasi di perairan Selatan Pulau Jawa lebih tinggi dibandingkan dengan kecelakaan kapal yang berbasis operasi di perairan Utara Pulau Jawa. LKF di Perairan Selatan Jawa 235/100.000 orang, jumlah rata-rata kapal tenggelam/hilang 4 unit kapal per tahun prosentase kapal yang hilang.

Penyebab korban meninggal/ hilangnya 23 orang korban pada kapal penangkap ikan di Kota Tegal adalah: 7 orang atau $30,43 \%$ terjatuh ke laut (man over board) pada saat melakukan penangkapan dan pelayaran, 7 orang atau $30,43 \%$ karena sakit, 6 orang atau $26,09 \%$ meninggal karena kapal terbalik disebabkan ombak besar dan terjepit gardan penarik tali slambar sebanyak 3 orang atau $13,04 \%$.

Tabel 7 Jenis kecelakaan fatal di atas kapal penangkap ikan kapal-kapal yang berbasis operasi di PPP Tegalsari, PPN Pekalongan, PPS Cilacap

\begin{tabular}{|c|c|c|c|c|c|c|c|}
\hline \multirow[t]{2}{*}{ No } & \multirow[t]{2}{*}{ Jenis kecelakaan } & \multicolumn{2}{|c|}{$\begin{array}{c}\text { PPP } \\
\text { Tegalsari }\end{array}$} & \multicolumn{2}{|c|}{ PPN Pekalongan } & \multicolumn{2}{|c|}{$\begin{array}{c}\text { PPS } \\
\text { Cilacap }\end{array}$} \\
\hline & & Jumlah & $\%$ & Jumlah & $\%$ & Jumlah & $\%$ \\
\hline 1. & $\begin{array}{l}\text { Jatuh/hilang di } \\
\text { laut }\end{array}$ & 7 & 30,43 & 3 & 25.00 & 8 & 24,24 \\
\hline 2. & Sakit & 7 & 30,43 & 7 & 58,33 & - & \\
\hline 3. & Kapal terbalik & 6 & 26,09 & - & & 25 & 75,76 \\
\hline 4. & $\begin{array}{l}\text { Penanganan alat } \\
\text { tangkap ikan/ } \\
\text { pengo- perasian }\end{array}$ & & & & & & \\
\hline & alat winch/gardan & 3 & 13,04 & 2 & 16,67 & - & - \\
\hline 5. & Jatuh di atas kapal & - & - & - & - & - & - \\
\hline 6. & $\begin{array}{l}\text { Pekerjaan } \\
\text { permesinan }\end{array}$ & - & - & - & - & - & - \\
\hline 7. & Asphyxiasi & - & - & - & - & - & - \\
\hline & Jumlah korban & 23 & 100 & 12 & 100 & 33 & 100 \\
\hline
\end{tabular}
$\begin{array}{clr}\text { Jenis } & \text { kecelakaan } & \text { yang } \\ \text { mengakibatkan } & 68 \text { korban meninggal/ }\end{array}$ hilang adalah: meninggal/hilang akibat kapal terbalik sebanyak 31 orang atau sebesar $45,59 \%, 18$ orang atau $26,47 \%$ meninggal/hilang jatuh ke laut, 14 orang atau $20,50 \%$ meninggal karena sakit dan kelelahan dan 5 orang meninggal/hilang atau $7,35 \%$ terjadi saat penanganan alat tangkap.

Dari prosentase tersebut korban meninggal/hilang akibat kapal terbalik terjadi di Cilacap sebesar $80,65 \%$, di Tegal $19,35 \%$ di Pekalongan tidak terjadi. Hal ini berkaitan dengan kondisi stabilitas kapal, ukuran kapal dan tingginya gelombang laut saat operasi penangkapan atau pelayaran.

Prosentase korban meninggal/hilang akibat jatuh ke laut (man over board) sebanyak 18 orang atau $26,4 \%$, terdiri dari: jatuh ke laut pada kapal-kapal minilongline, gillnet dan lampara di Cilacap sebanyak 8 orang atau $44,44 \%$, pada kapal cantrang di Tegal sebanyak 7 orang atau $38,89 \%$ dan pada kapal purseseine sebanyak 3 orang atau 16,67\%. Salah satu penyebab awak kapal jatuh ke laut disebabkan kapal yang dioperasikan 
untuk menangkap ikan yang berbasis operasi di PPP Tegal dan PPS Cilacap lebih kecil dibanding kapal-kapal yang berbasis operasi di PPN Pekalongan.

Prosentase meninggal di atas kapal karena sakit perlu mendapat perhatian karena data penelitian menunjukkan tingginya angka tersebut. Kapal-kapal yang berbasis operasi di PPN Pekalongan sebanyak 58,33\% akibat sakit, dan secara keseluruhan yang meninggal akibat sakit 20,50\% dari keseluruhan korban. Periode berlayar kapal purseseine yang berbasis operasi antara 34 hari sampai 89 hari dengan rata-rata berlayar 60 hari di laut. Menurut konvensi ILO (2007) dalam konvesi ILO Nomor 188 menyebutkan bahwa awak kapal penangkap ikan yang berlayar di laut lebih dari tiga hari harus memiliki kartu sehat dan di atas kapal harus tersedia obat-obatan dan awak kapal yang memiliki kompetensi perawatan medis (medical care), makanan dan air minum harus higienis. Pemeriksaan kesehatan bagi awak kapal sebelum berangkat belum terkontrol dengan baik.

Jenis kecelakaan pada saat penanganan alat tangkap yang meng- akibatkan meninggalnya awak kapal menunjukan 7,35\%, namun luka-luka berat dan ringan tidak ada data. Kejadian kecelakaan diakibatkan kurangnya pengalaman awak kapal atau awak kapal baru bekerja tanpa mendapat pelatihan terlebih dahulu, awak kapal kurang peduli atau tidak diberikan arahan dari nakhoda posisi-posisi yang membahayakan pada saat operasi penangkapan atau penyebab lain seperti kurangnya penerangan pada saat penurunan alat tangkap pada malam hari. IMO Model course 1.33 tentang keselamatan operasi penangkapan bagi awak kapal dapat dijadikan acuan untuk melatih awak kapal penangkap ikan selain pelatihan BST.

\subsection{Posisi Risiko Kecelakaan Kapal Penangkap Ikan di PPP Tegalsari, PPN Pekalongan dan PPS Cilacap}

Data kecelakaan armada kapal penangkap ikan yang berbasis operasi di PPP Tegal, PPN Pekalongan dan PPS Cilacap tahun 2006-2008 setelah dilukiskan pada kura F-N sebagaimana ditunjukkan pada Gambar 2 .

\begin{tabular}{|c|c|c|c|c|c|c|}
\hline & \multicolumn{6}{|c|}{ FREKUENSI } \\
\hline $\begin{array}{l}\text { Kecelakaan }>10 \\
\% \text { dari armada } \\
\text { kapal/tahun }\end{array}$ & $\begin{array}{l}\text { SANGAT } \\
\text { TINGGI }\end{array}$ & & & Mitigasi & & $\begin{array}{l}\text { UN-ACCDPT- } \\
\text { ABLE RISK }\end{array}$ \\
\hline $\begin{array}{l}\text { Kecelakaan } \\
1-<10 \% \text { dari } \\
\text { armada kapal/ } \\
\text { tahun }\end{array}$ & TINGGI & & & & $\begin{array}{l}\text { PPN } \\
\text { PEKA } \\
\text { LONG } \\
\text { AN }\end{array}$ & ac \\
\hline $\begin{array}{l}1 \text { kapal per } \\
\text { tahun }\end{array}$ & MEDIUM & & & $\begin{array}{l}\text { INTER- } \\
\text { MEDIATE }\end{array}$ & & \\
\hline $\begin{array}{l}1 \text { kapal per } 10 \\
\text { tahun }\end{array}$ & RENDAH & & & & & \\
\hline \multirow[t]{4}{*}{$\begin{array}{l}1 \text { kapal per } 100 \\
\text { tahun }\end{array}$} & $\begin{array}{l}\text { SANGAT } \\
\text { RENDAH }\end{array}$ & $\begin{array}{l}\text { ACCEPT- } \\
\text { ABLE } \\
\text { RISK }\end{array}$ & & & & $\begin{array}{l}\text { Penl ce- } \\
\text { Gol an }\end{array}$ \\
\hline & & $\begin{array}{l}\text { Sangat } \\
\text { ringan } \\
\text { (Minor) }\end{array}$ & Ringan & $\begin{array}{l}\text { Sedang } \\
\text { (Major) }\end{array}$ & Berat & $\begin{array}{l}\text { Sangat Berat } \\
\text { (Catastro- } \\
\text { phic) }\end{array}$ \\
\hline & \multicolumn{6}{|r|}{ KONSEKUENSI } \\
\hline & & $\begin{array}{l}\text { Kerusaka } \\
\text { n ringan, } \\
\text { keterlam- } \\
\text { batan }\end{array}$ & $\begin{array}{l}\text { Luka-luka } \\
\text { ringan }\end{array}$ & $\begin{array}{l}\text { Beberapa } \\
\text { terluka } \\
\text { berat, dan } \\
1 \text { orang } \\
\text { meningga } \\
1 / \text { hilang }\end{array}$ & $\begin{array}{l}2-10 \\
\text { orang } \\
\text { meningga } \\
1 / \text { hilang }\end{array}$ & $\begin{array}{l}>10 \text { awak } \\
\text { kapal } \\
\text { meninggal } \\
\text { dan kapal } \\
\text { tenggelam }\end{array}$ \\
\hline
\end{tabular}

Gambar 2 Kurva F- N Posisi Risiko Kecelakaan Kapal Penangkap Ikan di PPP Tegalsari, PPN Pekalongan dan PPS Cilacap. 

Pada kurva F-N menunjukkan bahwa kinerja keselamatan armada kapalkapal penangkap ikan yang berbasis operasi di PPP Tegalsari, PPN Pekalongan dan PPS Cilacap pada posisi risiko yang tidak dapat diterima. Posisi risiko kecelakaan kapal-kapal penangkap ikan di PPN Pekalongan relatif lebih rendah dibandingkan posisi keselamatan kapalkapal yang berbasis operasi di PPP Tegalsari dan PPS Cilacap pada posisi unacceptable risk.

\section{KESIMPULAN DAN SARAN}

Dari hasil penelitian dapat disimpulkan:

(1.) Nakhoda - nakhoda kapal-kapal penangkap ikan yang berbasis operasi di PPP Tegalsari, PPN Pekalongan dan PPS Cilacap belum memiliki kompetensi sesuai standar minimum yang dipersyaratkan nasional dan internasional ditinjau dari kompetensi navigasi, komunikasi dan keselamatan pelayaran dan penangkapan ikan.

(2.) Kapal-kapal penangkap ikan berukuran 10-129 GT di tiga lokasi penelitian, yang telah memenuhi peralatan keselamatan minimal di lokasi penelitian baru mencapai 29,69\%, sebanyak 70,31\% belum dilengkapi peralatan keselamatan sesuai persyaratan minimal.

(3.) Fatality Accident Rate (FAR) sebesar 115 orang atau 115 orang meninggal/hilang di laut per 100.000 awak kapal per tahun, angka tersebut lebih tinggi dari FAR kapal penangkap ikan dunia 80 orang meninggal/100.000 awak kapal.

(4.) Secara agregat posisi risiko kecelakaan kapal penangkap ikan di tiga lokasi penelitian berada pada posisi unacceptable risk artinya dalam kurun waktu satu tahun harus ada upaya-upaya penurunan risiko kecelakaan kapal-kapal yang berbasis operasi di PPP Tegalsari, PPN Pekalongan dan PPS Cilacap.

Rekomendasi upaya pencegahan dan mitigasi penurunanan risiko kecelakaan kapal penangkap ikan atas kondisi tingginya tingkat kecelakaan kapal-kapal penangkap ikan di PPP Tegalsari, PPN Pekalongan dan PPS Cilacap,sebagai berikut:
(1.) Perlu dibangun sistem statistik kecelakaan kapal penangkap ikan secara nasional dan bila perlu investigasi kecelakaan kapal penangkap ikan, menyelenggarakan risk assessment kecelakaan kapal penangkap ikan.

(2.) Peningkatan kualitas sumberdaya manusia Nakhoda dan ABK kapal penangkap ikan dan calon awak kapal penangkap ikan ukuran kurang dari 150 GT melalui paket pelatihan BST khusus untuk awak kapal penangkap ikan yang disesuaikan dengan kondisi tingkat pendidikan formal nelayan/awak kapal, kondisi kapal dan daerah pelayaran.

(3.) Peningkatan safety awareness melalui penyuluhan terhadap unsur terkait, seperti petugas Syahbandar Pelabuhan Perikanan, Pengawas Kapal Perikanan, Penyuluh Perikanan Tangkap, Pegawai Dinas Perikanan dan Kelautan, tenaga pengajar pada pendidikan dan pelatihan kepelautan perikanan; unsur non pemerintah seperti pemilik kapal, asosiasi pelaut perikanan, pemuka masyarakat nelayan, keluarga nelayan, perencana kapal dan pihak perencana dan pembuat kapal;

(4.) Meninjau ulang dan penegakan hukum atas peraturan tentang keselamatan kapal penangkap ikan terkait dengan: standar pendidikan dan pelatihan, ujian dan sertifikasi pelaut perikanan; standar pengawakan kapal penangkap ikan, standar kelaiklautan berbagai kelas kapal penangkap ikan dan sistem ketenagakerjaan pada kapal penangkap ikan;

(5.) Mengembangkan sistem kesehatan kerja dan asuransi kecelakaan bagi awak kapal penangkap ikan.

(6.) Mengembangkan sistem Search And Rescue.

\section{DAFTAR PUSTAKA}

Direktorat Jenderal Perikanan Tangkap, 2009. Statistik Perikanan Tangkap Indonesia 2009. Direktorat Jenderal Perikanan Tangkap. Departemen Kelautan dan Perikanan.

Departemen Perhubungan, 1996. Keputusan Menteri Perhubungan Nomor KM 46 Tahun 1996 tentang 
Sertifikasi Kelaiklautan

Penangkap Ikan. Jakarta.

FAO, 2000. The State of World Fisheries and Aquaculture. Part 2 Selected Issues Facing Fishers and Aquaculturists. Rome. Italy.

Forsman, Björn (2004). Application of Risk Assessment Tools in the Maritime Safety Management Process. MSM2004.SIDA. Sweden.

Gurdun Petursdottir, Olafur Hannibalson dan Jeremy MM. Turner (2001). Safety At Sea as an Integral Part of Fisheries Management. Food and Agriculture Organization of the United Nation. Rome.

International Maritime Organization, 2005. IMO Model Course 1.33. Safety of Fishing Operations (Support Level). 2005 Edition. Course + Compedium. London.
International Maritime Organization, 2007. Any Othre Business. Outcome of SLF 50.STW 39/11/1. Sub Committee on Standard of Training and Watchkeeping. 39th Session. London.

International Maritime Organization, 1995. 1993 Torremolinos Protocol and Torremolinos International Convention for the Safety of Fishing Vessels, Consolidated Edition, 1995. London.

International Maritime Organization, 1996. International Convention on Standars of Training, Certification and Watchkeeping for Fishing Vessel Personnel, 1995. London.

Jennifer M. Lincoln, Diana S. Hudson, George A. Conway and Rachel Pescatore, 2002. Proceeding of the International Fishing Industry Safety and Health Conference. US Department of Health and Human Services. 